\title{
FROM AUSTRALOPITHECUS TO CYBORGS. ARE WE FACING THE END OF HUMAN EVOLUTION?
}

\author{
Justo Aznar ${ }^{1}$, Enrique Burguete ${ }^{2}$
}

\begin{abstract}
Social implementation of post-humanism could affect the biological evolution of living beings and especially that of humans. This paper addresses the issue from the biological and anthropological-philosophical perspectives. From the biological perspective, reference is made first to the evolution of hominids until the emergence of Homo sapiens, and secondly, to the theories of evolution with special reference to their scientific foundation and the theory of extended heredity. In the anthropological-philosophical part, the paradigm is presented according to which human consciousness, in its emancipatory zeal against biological nature, must "appropriate" the roots of its physis to transcend the human and move towards a more "perfect" entity; we also assess the theory that refers this will to the awakening of the cosmic consciousness in our conscious matter. Finally, it assesses whether this post-humanist emancipatory paradigm implies true evolution or, instead, an involution to the primitive state of nature.
\end{abstract}

Keywords: theories of evolution, Australopithecus, cyborgs, post-humanism, transhumanism, somatechnics

\section{De Australopithecus a cyborgs. ¿̨Nos enfrentamos al final de la evolución humana?}

Resumen: La implementación social del poshumanismo podría afectar la evolución biológica de los seres vivos y, especialmente, la de los humanos. Este artículo aborda el tema desde las perspectivas biológica y antropológico-filosófica. Desde la perspectiva biológica, se hace referencia, en primer lugar, a la evolución de los homínidos hasta la aparición del Homo sapiens, y en segundo lugar a las teorías de la evolución, con especial referencia a su fundamento científico y a la teoría de la herencia extendida. En la parte antropológico-filosófica se presenta el paradigma según el cual la conciencia humana, en su afán emancipador frente a la naturaleza biológica, debe "apropiarse" de las raíces de su physis para trascender lo humano y avanzar hacia una entidad más "perfecta"; evalúa también la teoría que refiere esta voluntad al despertar de la conciencia cósmica en nuestra materia consciente. Finalmente, juzga si este paradigma emancipatorio poshumanista implica una verdadera evolución o, en cambio, una involución al primitivo estado de naturaleza.

Palabras clave: teorías de la evolución, Australopithecus, cyborgs, posthumanismo, transhumanismo, técnica somática

\section{Do Australopithecus aos ciborgues. Estamos diante do fim da evoluçáo humana?}

Resumo: A implementação social do pós-humanismo pode afetar a evolução biológica dos seres vivos e especialmente dos humanos. Esse artigo aborda o problema de perspectivas biológicas e antropológico-filosófica. Desde uma perspectiva biológica, é feito referencia primeiro à evolução de hominídeos até a emergência do Homo sapiens e, em seguida, às teorias da evolução, com especial referencia ao seu fundamento científico e à teoria da hereditariedade estendida. Na parte antropológico-filosófica, o paradigma é apresentado de acordo com o qual a consciência humana, em seu zelo emancipatório da natureza biológica, deve "apropriar" as raízes da sua natureza para transcender o humano e se mover em direção a uma entidade mais "perfeita": nós também avaliamos a teoria que refere este desejo ao despertar da consciência cósmica em nossa matéria consciente. Finalmente, ele avalia se este paradigma emancipatório pós-humanista implica evoluçáo verdadeira ou, contrariamente, uma involução para o estado primitivo da natureza.

Palavras chave: teorias da evolução, Australopithecus, ciborgues, pós-humanismo, transhumanismo, somatécnica

\footnotetext{
${ }^{1}$ Institute of Life Sciences, Catholic University of Valencia, Spain. ORCID: https://orcid.org/0000-0002-6899-4932 Correspondence: justo.aznar@ucv.es

${ }^{2}$ Catholic University of Valencia, Spain. ORCID: https://orcid.org/0000-0002-0691-8846
} 


\section{From Australopithecus to Homo sapiens}

Biological evolution could be coming to an end, because man has been gradually acquiring a technological power that allows him to bring about changes in the nature of living beings, and even in his own self. It may be, as Yuval Noah Harari suggests, that "we are on the cusp of a new era of selfguided evolution enabled by genetic engineering technologies and driven by the desire to 'improve' our bodies and minds"(1).

This has been extensively discussed by the recent winner of the Nobel Prize in Chemistry, Jennifer A. Doudna, in her book "A Crack in Creation. Gene Editing and Unthinkable Power to Control Evolution", where, in addition to describing the discovery of CRISPR-Cas 9 technology, she contends that this may be the newest and most effective genetic engineering tool, and that CRISPR could put the process of biological evolution under human control(2).

Organic life appeared on earth around 3800 million years ago. Since then, and from the first single-celled organisms, living beings have evolved to reach the somatic fullness - the phenotype- of non-human primates, orangutans and Homo sapiens.

Homo sapiens split from orangutans and chimpanzees approximately 8 and 5 million years ago, respectively(3). Some organic structures of these hominins have undergone changes since early genus Homo, especially the brain, which increased in size from $450 \mathrm{~cm}^{3}$ in primitive hominins to 1350 $\mathrm{cm}^{3}$ in modern humans.

The first question that arises when reflecting on the evolution of the genus Homo is to determine, with the greatest possible certainty, who our early ancestors were. The first hominins separated from gorillas 8 million years ago, and that humans and chimpanzee lineages did so around 5 million years ago. However, this dating cannot be considered definitive due to a lack of fossil data from that time(4).

Nevertheless, these doubts appeared to be resolved when, in 1973, Mary Leakey and Donald Johanson discovered fossil remains of hominins of be- tween 3 and 3.5 million years old in east Africa. This genus was called Australopithecus afarensis and the individual fossil discovered was called "Lucy". The inclusion of Lucy within the genus Homo was based on her bipedalism, a feature that has been considered as definitive for classifying an individual as the genus Homo. At that time, Lucy was considered the oldest individual of that genus(4).

The other feature that gives these ancestors —our predecessors - human character, is the size of their brain. As already mentioned, Lucy's brain was similar in size to that of an adult chimpanzee, and even its overall phenotype was more like a chimpanzee than a primitive human.

For a long time, Australopithecus afarensis was considered the oldest hominin, but in the mid-1990s, others were discovered, apparently older than $A$. afarensis. One of these, Australopithecus anamensis, also biped, was ascribed an age of 4.1 million years(3).

Other hominins, part-contemporaries of Australopithecus, were Kenyanthropus and Paranthropus. Paranthropus represents a side branch of the hominin lineage that has become extinct(5). Other species of the genus Australopithecus have also been identified, such as Australopithecus: bahrelghazali, platyops, africanus, garhi and sediba(6).

About 2.5 million years ago, Homo habilis, which had a cranial capacity of just over $600 \mathrm{~cm}^{3}$, and Homo erectus, with a cranial capacity of 800 to $1100 \mathrm{~cm}^{3}$, lived in Africa(5). Homo erectus was the first intercontinental migrant among our hominin ancestors, for shortly after their emergence in Africa, they spread across Europe and Asia, even reaching the Indonesian archipelago and northern China. Both the fossils of Homo erectus discovered in Java and those discovered in Georgia were deemed to be between 1.8 and 1.6 million years $\operatorname{old}(5)$.

In the mid-1970s, Richard Leakey, son of Mary Leakey and her anthropologist husband Louis, discovered a very well preserved skull fossil in Koobi Fora (Kenya), which was classified as specimen KNM-ER 1470(3); it was included within the species Homo habilis and ascribed an age of 2.42 million years(3). 
However, large intraspecific variation was detected in the Homo habilis fossil remains found, so some of these specimens, especially those with larger skulls, were redefined as Homo rudolfensis(3). This genus was confirmed when another fossil skull, also classified within the species Homo was likewise discovered in Koobi Fora(3), which seems to support the theory that two species of Homo existed 2 million years ago in Africa: habilis and rudolfensis.

However, in the early twenty-first century, three new candidates for the oldest hominin were discovered: Sahelanthropus tchandensis, who lived 6 or 7 million years ago; Orirrin tugenesis, discovered in Tugen, Kenya, thought to be 6 to 7 million years old; and Ardipithecus ramidus discovered in Europe, 4.4 million years old(4), although it is not fully clear whether these last three "could be variants of the various lineages of apes that existed before the true 'hominins' appeared(4)". Therefore, Australopithecus - either aferesis or anamensis generally tends to be considered our earliest ancestors, with an age of around 3 million years(4).

As previously mentioned, notwithstanding the fossils discovered in Africa in 1921 and 1923, fossil remains were discovered in Zhoukoudian, China, known as "Peking Man", which were classified as Sinanthropus pekinensis(3).

Also in 1891, fossil remains were discovered on the island of Java, and accordingly named "Java Man", with these hominin remains seemingly the oldest discovered in Asia. Although it had a smaller brain than modern humans, because it walked upright, its discoverer, Eugene Dubois, placed it within the genus Homo and called it Pithecanthropus erectus(3). In the 1990s, "Java Man" was ascribed an age of 1.8 million years(3), very similar to that of the African Homo erectus, which has been a hindrance to be able to say that the Asian Homo erectus could be a direct descendant of the African erectus.

Another difficulty arose from the discovery of fossil remains in Dmanisi, Georgia, in 1991, because they were also ascribed an age of 1.8 million years(3).

Another group of hominins are the "Neander- thals", who appeared in Europe 200,000 years ago and survived until 30,000 years ago. The first Neanderthal fossil was discovered in 1856 in the Neander Valley near Dusseldorf (Germany), and classified by William King as Homo neanderthalensis. Based on this first taxonomic classification, up to 34 different species and six genera of Neanderthals have been proposed(3). In terms of their relationship with Homo sapiens, the most widely accepted theory is that Neanderthals and Homo sapiens are two different species, two sister groups of the genus Homo.

Neanderthals were eliminated by modern humans, the "Cro-Magnons" (4). Although it was initially thought that the Neanderthals had not interbred with Homo sapiens, in 2010, Svante Pääbo showed that both species would have hybridised, as about $4 \%$ of genes in modern humans are of Neanderthal origin(3)(4). Incidentally, these genes control important functions such as smell, vision, cell division, spermatogenesis, the immune system, muscle contraction and language(4).

Apparently, though, the hominin species does not end here since, in October 2004, the journal Nature published the finding by Michael Morwood and colleagues of a tiny hominin fossil on the Island of Flores, which they called Homo florisiensis; the fossil had a very small body and a tiny brain, even smaller than that of a newborn human, and lived on the island between 60,000 and 18,000 years ago (4). How that group of hominins arrived on Flores and the reason for their small size is currently unknown.

In 2010, new skeletal remains were discovered in the region of Altair (Russia) in Denisova Cave, which were apparently about 100,000 years old. Following DNA tests, they were classified as a human species, different from the Neanderthals and modern humans. Individuals of this new species have been named "Denisovans" $(3,4)$. The Denisovans spread across Asia, from 125,000 until 12,000 years ago and interbred with humans present there, which has been confirmed by the finding of around $3 \%$ of Denisovan genes in modern humans $(3,4)$.

Besides the aspects discussed thus far in relation to the genus Homo, one subject that has fascinat- 
ed paleoanthropologists is whether Homo sapiens originated from a single population or from several species, and in one or different places.

Using a genetic evolution technique called the "molecular clock", it has been possible to calculate the time elapsed from the moment a gene originates until the present time, by the number of mutations found therein.

The molecular clock is based on "the probability that the changes in a given gene are constant, since the protein function does not change and is, therefore, outside natural selection. Thus, the difference in the number of changes found between the genes of two species can be used to calculate the time elapsed from a given time to their common ancestor". Accordingly, using the molecular clock, we can reconstruct the evolutionary history and branching order of different human lineages $(3,4)$.

Using the molecular clock, it has been determined that modern humans emerged in east Africa less than 200,000 years ago(4). That is to say, as modern humans expanded their migrations outside Africa, they would have eliminated the rest of the hominins they encountered in the territories that they took over, imposing themselves as the only hominins who survived on earth, from which we are descended. This model has been called the "complete replacement model"(4).

But there is another option, which holds that "modern humans did not originate in a specific place, but in various places, and did not constitute a single population, which then spread throughout the world; rather, we come from different populations settled in different regions, which were genetically intermingled and that evolved as a unique species"(4). This model has been called the "multiregional evolution model" $(3,4)$. According to Cela-Conde and Ayala(3), neither of the two models - the "replacement" or the "multiregional" - can be regarded as definitive, although the evidence available today supports the idea that modern humans arose in Africa and subsequently expanded into other continents, so that "at the present time, there is little doubt that Africa was the cradle of the hominins"(3).

Af Nevertheless, as Lee and Yoon said in their recent book, the fundamental questions remain unresolved: Where do modern humans come from? What paths have they followed to get to where we are today? And where will our human journey lead?(4). Moreover, "for now, we do not have even basic information on how Homo sapiens emerged" (6).

In addition to the foregoing, it may be said that the mechanisms that have governed the evolution of living beings to modern man are not fully understood, although the "Theory of Evolution" is the one that prevails in the scientific field. We shall refer to this in the next chapter.

\section{The Theory of Evolution}

In his 1859 book "On the Origin of Species", Darwin stated that the development and evolution of living beings is governed by natural selection, which makes the fittest prevail and eliminates the weakest(6). If we accept this theory, it could be said that living beings themselves and species are not immutable, and that differences in their phenotypes are the consequence of the aforementioned biological evolution(6). By focusing his evolutionary theory exclusively on natural biological mechanisms, Darwin excludes the purpose in evolution, that is, the teleology. As Darwin himself says: "It seems that there is no [more] design in the variability of organic beings and in [the action of] natural selection [than in the course which the wind blows]"(7).

However, his contemporary Alfred Russel Wallace argues that natural selection does not seem to be sufficient to explain the origin of the human species. According to him, we humans would not have become what we are if only the aforementioned natural selection had been taken into account (8), so that he somehow introduces the possibility of an external - possibly divine- intervention in the evolutionary process itself.

According to Cela-Conde and Ayala, when studying the Theory of Evolution, three different aspects need to be examined: "The first is the fact of evolution itself, that is, the finding that species change over time and are related to each other"; the second is its history, and the third refers to the causes of evolution, "this is the processes that de- 
termine the morphological, physiological and behavioural characteristics of organisms in particular and the relationships that exist between them"(3).

After the theories proposed by Darwin and Wallace, a breakthrough in understanding the mechanisms of "biological evolution" occurred with the discovery in 1900 of the "Mendelian Theory of Inheritance", which emphasizes the role of heredity in the offspring.

Darwinian Theory was redefined in 1930 by Theodosius Dobzhansky, in his book "Genetics and the Origin of Species" by combining natural selection with Mendelian inheritance(9). As CelaConde and Ayala said, this work by Dobzhansky could be considered the most important contribution in what is known as the "Synthetic Theory" or "Modern Theory of Evolution"(3).

Over time, a series of unified principles have gradually been added to the Synthetic Theory, which have led to what has been termed "Modern Synthesis" or "neo-Darwinism" (10); this espouses that biological evolution is the result of the interaction of two main forces: genetic variation and natural selection. In short, it could be argued that neoDarwinism is defined by ongoing genetic changes in individuals as a result of random processes, with no control mechanism or particular system directing these mutations to purposes that benefit the individuals concerned; thus it is natural selection that is the main regulatory factor of evolution(11). In the words of Richard Dawkins, the Modern Synthesis or neo-Darwinian Synthesis of Evolution is a mechanistic theory of population genetics which is based on the randomness of mutations, and excludes any purpose in the evolutionary pro$\operatorname{cess}(12)$.

Ernst Mayr, one of the founders of neo-Darwinism, distinguishes between "microevolution" and "macroevolution"(13). In his view, microevolution refers to the changes that can occur within the same species, while macroevolution refers to changes at the highest level of biological classification.

To sum up, according to Artigas and Turbón(14), the Synthetic Theory is characterized by the interaction of five factors: (a) mutations or random changes in the inherited genetic material; (b) genetic recombination thereof; (c) genetic drift or random changes in the frequency of genetic variants; (d) genetic migration, which incorporates individual carriers of different genetic variations in the reproductive group, and (e) finally, the natural selection caused mainly by the environment.

In both the Darwinian Theory and the Synthetic or neo-Darwinian Theory, evolution occurs by the slow and inexorable accumulation of small genetic variations (mutations) and by natural selection of the new beings produced. "Genetic mutations may be of two categories: point mutations affecting only one or a few nucleotides of a gene; and chromosome mutations, affecting, partially or completely, one or more chromosomes and which can change the organization of a given chromosome or even affect the number of chromosomes"(3).

In 1968, Japanese geneticist Motoo Kimura proposed what he called the "Neutral Theory" of molecular evolution. It posits that "a great part of the genetic variation observed in populations and species is due to the fluctuation and random fixation in the genome of neutral genetic variants" (15), so that "many of the changes that take place in the DNA and protein sequences are adaptively neutral, that is to say, they have little or no effect on the function of the molecules"(3).

In 1983, Kimura, in collaboration with Tomoko Ohta, developed the so-called "Neutral Theory of Molecular Evolution", which contributed decisively to acceptance of the Neutral Theory as one more possibility within biological evolution(16).

In the 1970s, Stephen Jay Gould(17) proposed a new alternative to biological evolution, which he called the "Punctuated Equilibrium Theory"; this argues that the emergence of new strains of living organisms occurred abruptly or in "jumps", but after such "jumps" there might be periods of certain equilibrium, i.e. periods of slow evolution. In a way, the latter allows the Synthetic Theory of Evolution and the Punctuated Equilibrium Theory to be combined.

However, some authors argue that there is a need to develop a "postmodern" synthesis of the The- 
ory of Evolution following the incorporation of new forms of hereditary transmission, that have expanded the neo-Darwinian Evolutionary Theory $(18,19)$, the most significant of which, in our view, is so-called "Extended Heredity".

\section{Theory of Extended Heredity}

The mechanisms of action of Extended Heredity were studied in depth by Russell Bonduriansky and Troy Day in their recent book "Extended Heredity" (20), in which they essentially claim that non-genetic acquired factors can be transmitted to offspring.

Indeed, until recently, it was thought that acquired traits could not be inherited, as it was believed that only genes could mediate in the transmission of biological information. However, according to the theory of Extended Heredity, "there is also nongenetic inheritance, in which other factors that are transmitted to offspring may play a role, some of which have the capacity to regenerate themselves and persist over multiple generations"(20). It can therefore be said that "[g]enes have a great deal of influence [on evolutionary processes] but their control is far from absolute", because there is "empirical evidence revealing that there is often much more to heredity than genes alone"(20). According Bonduriansky and Day, acceptance of the concept of Extended Heredity may revolutionize our ideas about biological evolutionary processes(20).

Among the non-genetic factors involved in Extended Heredity, epigenetic factors play an important role. But what do we mean when we talk about epigenetic factors?

The term epigenetics "is used in the 'broad sense' by evolutionary ecologists and developmental biologists to try to explain how environmental factors can shape the phenotypes of living beings, but it is also used in a 'narrower sense' by molecular biologists to try to further understand the mechanisms that regulate gene expression. In other words, the first definition primarily affects the constitution of phenotypes, while the second, narrower, particularly affects the molecular mechanisms"(20).

Bonduriansky and Day restrict the term epige- netic, in relation to biological evolution, to the "narrower sense" referred to above. In their view, epigenetic changes can be passed on through generations, independently of the genes, affecting the mechanisms of inheritance(20), which forms the basis of so-called "transgenerational epigenetic inheritance"(21).

However, transgenerational epigenetic inheritance is not the only form of non-genetic inheritance, as other non-genetic mechanisms may also facilitate the transmission of information to offspring and affect biological evolution. These might include: cytoplasmic, structural, symbiotic and behavioural factors. As Bonduriansky and Day contend, "in the exciting field of epigenetics it is easy to forget that this heredity is only one possibility among the various mechanisms that may occur in nongenetic inheritance" (20).

Among the non-epigenetic mechanisms of biological inheritance, so-called "niche construction" has been proposed. This refers to the fact that the environment in which a biological process develops can influence the evolutionary process itself and, above all, to how changes could be transmitted to offspring(22).

There is also the theory of "phenotypic plasticity" (23), which could be defined as the ability of an organism to change its phenotype in response to environmental influences(24), so that the shape, appearance and behaviour of a living animal, i.e. its phenotype, may be influenced by factors external to it.

Furthermore, Shapiro et al.(25) propose the existence of natural genetic engineering. This would act similarly to laboratory genetic engineering, because in their view, the cell genome is not just a repository of information, but rather a reading system that can be manipulated by the cell itself, since it has a biological system that can direct the information towards a specific purpose, so that the cells can use these capabilities to self-regulate their own evolution(26).

As Bonduriansky and Day argue, "today the existence of nongenetic inheritance is no longer in question [...]. But the role of nongenetic inheritance in evolution is much more difficult to estab- 
lish". Nevertheless, in their opinion, its existence is indisputable, since they believe that all of the necessary conditions arise to assume that some non-genetic factors are transmitted stably across generations. If all this is confirmed, as seems to be the case, we will need to rethink the evolutionary history of humans, since the concept of Extended Heredity undoubtedly represents a break with the past (26).

In any case, the evolutionary mechanisms considered up to this point essentially respond to what have been called "minor transitions" in the evolutionary process, i.e. to "microevolution", in the sense that it uses this concept; however, "macroevolution"(13), the major evolutionary transactions, and essentially the production of new species, seems a problem not yet well elucidated. Even Charles Darwin, in his book "The Origin of Species", did not devote much attention to the process by which new species emerge(20), among other reasons because of the difficulty in accepting a definition of species. Species can also be defined as a group of individuals that has the potential to interbreed and that is reproductively isolated from other such groups(27). For Mayr, "a species is a group of natural populations that have the potential to interbreed and are reproductively isolated from other groups of populations" (28), or it can also be defined as "a single lineage of ancestral descendant populations of organisms which maintains its identity from other such lineages and which has its own evolutionary tendencies and historical fate" (Wiley)(29). The emergence of a new species is a process by which a group of individuals splits off from a previous species and reaches the possibility of reproducing separately from their ancestral group (20).

With regard to potential mechanisms of speciation, some time ago Sewall Wright proposed a mechanism based on the fact that certain groups of individuals can grow to a maximum peak, which can then descend to a minimum level, and then increase again to another peak. From one of those peaks, its individuals can reproduce and evolve in isolation, which can lead to a new species(30).

In the late sixties, Lynn Margulis proposed a new theory to support the origin of new species, suggesting that they could be obtained by the symbi- osis of two primitive species, for example, from an archaea (prokaryote) and a bacterium, biologically active cells $(20,31)$.

More recently, John Maynard Smith and Eörs Szathmáry revisited this same theory to support the emergence of eukaryotic cells through the symbiosis of archaea (prokaryotes) and bacteria $(20,32)$.

Without a doubt though, aside from the mechanisms proposed to support the aforementioned biological evolution, an important background aspect is to determine whether evolutionary processes occur randomly, i.e. if they occur at random or if there is any kind of purpose in them. We shall not refer to this in depth here, which we have already done in a previous paper(33), but we shall reflect briefly on the importance of the issue. The core of the matter is to determine whether or not there is teleology in biological evolution, or if at least, if one does not want to accept teleology, one acknowledges the existence of self-regulatory mechanisms in the genomic structure of living beings that can propitiate their evolution towards some specific purpose. This is what has been called "teleonomy", a term which - since it does not require any external intervention - has greater acceptance among moderate evolutionists. This biological mechanism has been called the "Theory of Self-regulation".

However, in addition to the biological mechanisms discussed, we may add the potential to artificially modify the biological evolutionary process. Indeed, Doudna, in her aforementioned book, "A Crack in Evolution," suggests the possibility that by using genetic editing with CRISPR-Cas 9 , man could, in some way, modify the biological evolutionary process(2). For about the hundred thousand years of modern human existence, the genome of Homo sapiens has been modelled by the twin forces of random mutation and natural selection. Now, for the first time, we possess the ability to edit not only the DNA of any living human being, but also the DNA of future generations; in essence, to direct the evolution of our own species. This is something unprecedented in the history of life on $\operatorname{Earth}(34)$.

\section{Technogenesis of the Posthuman or anthro- pogenesis of the humanoid robot}


Taken to the extreme, the rationalizing paradigm described by Max Weber(35) in the middle of the last century - whose main indicators are calculability, efficiency and predictability- could allow us to control our own destiny as individuals and as a species, with the help of technology. In fact, in 2003, a report by the National Science Foundation (NSF)(36) showed their confidence that the convergence of sciences such as nanotechnology, biotechnology, information technology and cognitive sciences (NBIC) would allow evolution to be technologically re-launched to achieve a new type of man in endless progress, a man impervious to disease and aging. This "re-launch" would start with the "biologization" of the artificial by biomimicry.

The confidence of the NSF in NBIC convergence is not entirely unfounded. At the end of the day, there are few in the twenty-first century who can say that their feelings and dreams are not mediated by technology (37). Perhaps for this reason, enhancement (a term used to designate interventions to improve human functioning beyond what is necessary to sustain or restore good health(38) is an increasingly used concept in the language of philosophy and biomedicine.

The transhumanist movement believes that enhancement is not an option, but a duty. It affirms, in fact, the "moral duty to improve physical and cognitive capabilities of the human species, and to apply new technologies to man to eliminate undesirable and unnecessary aspects of the human condition, such as: suffering, sickness, aging, and even the mortal condition"(38). Its initial supposition is that aging brings no biological benefit to the individual and death is but a correctable side effect of natural selection; the expression of its resounding failure at having been unable to facilitate mechanisms of repair, regeneration and renewal of biological structures(39).

Epistemologically, transhumanism is rooted in the hermeneutics of evolutionism and technology (37) conjectured in 1923 by Julian Huxley, who predicted the possibility of "the education of old faculties to new heights, and of the discovery of new faculties altogether" (40). Against the randomness and margin of error of natural selection, compared by Dawkins with a 'Blind Watchmaker'(41), man would have the responsibility to establish a "conscious evolution".

In fact, with Huxley began a new evolutionary paradigm based on the potential ability of human consciousness to penetrate the roots of biology in order to provide vision, direction and guidance for the flourishing of "a new kind (of life) that will be the dominant and highest life form"(39). This new kind of life will be, in the first instance, an "enhanced human" or transhuman which will later transition to the posthuman: a being "more perfect" than its predecessors and that will take our species to the culmination of its essence in terms of the fulfilment of its rationality and will(42). The posthuman will prolong his life without decline, will have a greater intellectual capacity and absolute control of his emotions. In short, he will enjoy a body in accordance with his wishes, which will be able to produce copies of itself(43), confining the human to the status of an evolutionary episode already surpassed whose only greatness, as Nietzsche said(44), lies in being a bridge and not an end: a transition and a decline.

Transhumanism and posthumanism therefore understand natural selection as the "prehistory" of a dual evolutionary sequence not yet completed, albeit in an advanced stage of development: technogenesis of the posthuman(45) and anthropogenesis of the humanoid.

\section{Cosmic consciousness as an engine of evolution}

For transhumanism, the engine of evolution is not the random mutation of genes or the filter of natural selection(46), but the will, essence of reality and the universe, although man's task. Hybridization between the natural and the artificial, between human consciousness and artificial intelligence, requires the acquiescence of humans, but does not respond to their original initiative. Rather, it would be the universe itself who would have "endowed itself with small representations of itself or with sparks of a more intense subsequent moment"(47), in which human consciousness becomes universal consciousness and brings the development of nature to its fullness. For Kurzweil, our identity is based on an evolving mind file when we take the huge step of replicating ourselves in computer technology. In his own words, 
"we will be software, not hardware" (48).

For transhumanists, it seems time to evolve past Logos consciousness to form Holos consciousness(49); to take responsibility for the evolution of the cosmos with which we are one; to transcend ourselves to energize and direct our evolution towards a new asexual, immortal, hybrid and profoundly egalitarian species $(50,51)$, in which there is no place for selfishness, anger or the cruelty of human nature.

\section{Somatechnics, enhancement and eliminative ma- terialism}

There is no doubt that man is more than nature and that his evolution would not be explained without technology. But while human technology transformed the world, it has also transformed man himself. To explain this phenomenon, the concept somatechnics is gaining strength; this states that man is nothing but embodied technology(52). Indeed, there is some truth in this, because our body is actively involved in the reception of technological changes, as evidenced by the plastic properties of the central nervous system(52). Therefore, for transhumanism, it is meaningless to claim that technological or biomedical modification of the body could adversely affect our nature, because it was never anything other than embodied technology.

Nevertheless, to date, technoscientific intervention on our nature has not exceeded the human and its function has been strictly therapeutic and of adaptation to the natural environment and social life. Today, however, technology allows transformations of the human body that go beyond therapy to improve the physical, cognitive and even moral conditions of man, taking him to limits that transcend his nature.

In practice, setting the ethical boundaries between therapy and enhancement may be difficult, because as people we define ourselves by a free will "in itself" that transcends us and gives us the power to decide the "where" to which to turn as our good or end(53). The properly human act, in short, is not impulse, but praxis. The impulse is a creation of nature, but the praxis is what follows the impulse. Hence, it is correct to say of man that he is a being destined, "by nature", to intentionally go beyond his nature(54) through praxis and under the guidance of his reason.

In this regard, prolonging life and overcoming the limits of our nature is a purely human desire that posthumanism takes to its logical conclusion.

\section{Posthumanism and progress}

Is post-humanism a true evolution or progress? To answer this question, we will distinguish, with Robert Spaemann, between two types of progress according to the end to further. Thus, there is progress that makes sense thanks to the achievement of an end and progress that is an "improvement", regardless of the end. An example of the first type would be the progress that takes place in the construction of a machine, because none of it would make sense if it was never built and operated. In the second type of progress, in contrast, the telos of the process is already done when the improvement begins.

The latter is, we believe, the case of man understood as an end in himself and already accomplished, although in changing conditions; as "someone" — and not "something" — for whom progress implies maturation, deployment and a good life(55); as someone who is defined by his substance and not by all of his accidents. Thus, progress referring to man does not imply the production of a final whole but service to an already existing end(54).

That said, who is it then who would progress if the transhumanist project is consummated? $\mathrm{Hu}$ manity, understood as an abstract group, at being expanded? Or individual self-awareness that could unfold in the space of its essence, free from the natural constraints that it did not choose?

It would hardly be humanity, because it is not independent of the historical, natural and cosmic conditions that constitute its vital space, nor of the moral norms that continue to be constituted by individuals who, while belonging to a biological species, are also persons(54). Furthermore, "humanity is not the subject of a common desire to which progress or setbacks can be attributed. Rather, the normal thing in progress attributed to 
collective subjects that some groups improve 'at the expense of' or in comparison with others" (54). In this respect, a transhuman future would widen the gap between those who possess the technological and economic capacity "to improve oneself" and those who do not.

The problem of giving meaning and substance to a life of indefinite duration, avoiding boredom and finding ways to maintain a coherent personal identity must also be considered. If human living has a projective character(56) and our destiny is constructed by the indirect influence that each of our actions and omissions exerts on us, it would be foolish to forget that there is a "before" and "after" these. Should we then worry endlessly about the consequences of our present actions on a future individual who will probably have difficulty identifying with the "I" that we are today? Or as Antonio Diéguez wonders, what consequences will hyper-extended longevity have on our social and family relationships?(57).

Special mention should be made of the social consequences of a perpetually aging population. How many years then would the improved and hedonistic individual to whom posthumanism aspires have to work? There will be those who will say none, since it will be the machines who work for him. But this must also be able to withstand two objections: the first, how to fill the hours of a quasi-eternal life, devoted entirely to leisure; and the second, if humanoid robots - when artificial intelligence becomes self-aware- will agree to be our slaves.

Moreover, if the posthuman is a cyborg whose operating system incorporates the synaptic matrix of a scanned human brain —or a chip that houses the memories and experiences of what was once a man- several questions arise: Would consciousness downloaded onto a computer support retain its previous marital status? Who will authorize the digital copy and download of a consciousness? Who will own the rights to download the consciousness of a famous person or a Nobel Prize winner?

The issue does not improve when we consider progress on individual self-awareness understood as a "bundle of sensations". For although his emanci- pation from the physical restraints that limit and engender pain could be considered progress, the question arises as to whether subjective well-being is the ultimate end of a rational individual. Because if it were, progress would arrive earlier with the administration of narcotic drugs that would induce states of euphoria, tearing consciousness apart from all contact with reality.

In any case, it makes sense that when the natural is presented as something from which to be emancipated, it is "the artificial" that carries out the transformation of the natural into artifactual. Until the artificial possesses that capacity, it would be posthumanist "engineers" who would design evolution, probably eliminating the "defective ones" for eugenic reasons. Thus, the ethical conception which has its foundation -as Jürgen Habermas (58) suggests - in the moral autonomy of rational beings would be undermined.

It may be concluded, therefore, that the emancipatory goal of transhumanism and its idea of improvement are unpursuable myths. When the idea of progress disparages the limits of natural organization, we cannot speak of true progress.

\section{Conclusions}

Organic life appeared on earth around $3800 \mathrm{mi}-$ llion years ago. Since then, and from the first single-celled organisms, living beings have evolved to reach the somatic fullness - the phenotype - of non-human primates, orangutans and Homo sapiens.

Homo sapiens split from orangutans and chimpanzees approximately 8 and 5 million years ago, respectively(3).

Some organic structures of these hominins have undergone changes since early genus Homo, especially the brain, which increased in size from 450 $\mathrm{cm}^{3}$ in primitive hominins to $1350 \mathrm{~cm}^{3}$ in modern humans.

In his 1859 book On the Origin of Species, Darwin stated that the development and evolution of living beings is governed by natural selection, which makes the fittest prevail and eliminates the weakest(6). If we accept this theory, it could be said 
that living beings themselves and species are not immutable, and that differences in their phenotypes are the consequence of the aforementioned biological evolution(6).

The transhumanist paradigm understands "humanity" as a bridge to a higher way of life. It is, therefore, an evolutionary episode, a form of life that must hybridize with the artificial in order to overcome its vulnerability to disease and death. This hybridization should not be avoided, as it constitutes a requirement of universal consciousness that is expressed in a small representation of itself: human consciousness. Assuming our responsibility in the evolution of cosmic consciousness also implies being willing to replicate our personal consciousness in information technology to expand as software on more efficient supports than our limited biology.

Our reflection, on the basis of metaphysical realism, concludes that the trans and posthumanist paradigm does not constitute an evolution or progress. People are not independent of the historical and natural conditions that constitute our living space, nor of the moral norms that derive from our "personal" as well as biological character.
It is also concluded that there are many problems associated with the transhuman and post-human horizons. A transhuman society would widen the gap between social classes as a consequence of the different capacities of access to improvement technologies. It would also suppose the appearance of mental and moral problems to give meaning and coherence to a life not threatened by the imminence of death. It would also involve demographic and social and family relationship problems as a consequence of hyperextended longevity. The posthuman horizon, for its part, raises doubts in relation to the ownership and subsequent use of the "software" to which personal identity would be reduced.

It is concluded, therefore, that the emancipatory objective of transhumanism and its idea of improvement are false myths that underestimate the self-limiting character of natural organization.

There are no conflicts of interest. 
From Australopithecus to cyborgs. Are we facing the end of human evolution? - Justo Aznar, Enrique Burguete

\section{References}

1. Harari YN. Homo Deus: A Brief History of Tomorrow. London: Harvill Secker; 2016.

2. Doudna JA, Sternberg S H. A Crack in Creation: Gene Editing and the Unthinkable Power to Control Evolution. Boston: Houghton Mifflin Harcourt; 2017.

3. Cela Conde CJ, Ayala FJ. Evolución Humana. El camino hacia nuestra especie. Madrid: Alianza; 2013: 173.

4. Lee SH, Yoon SY. ;No seas neandertal! y otras historias sobre la evolución humana. Barcelona: Debate; 2018: 47.

5. Ayala FJ. ¿Clonar humanos? Limites de la eugenesia. ARBOR Ciencia, Pensamiento y Cultura; 2019: 195-792.

6. Darwin Ch. The origin of species. Oxford: Oxford University Press; 1996.

7. Darwin C. In Darwin F. The Life and Letters of Charles Darwin, vol 1. New York: Appleton; 1897: 278-279.

8. Berry A. Wallace, el evolucionismo radical. Investigación y Ciencia 2013 Octubre: 41.

9. Dobzhansky T. Genetics and the Origin of Species. Nueva York: Columbia University Press; 1937.

10. Bartlett J. Evolutionary teleonomy as a unifying principle for the extended evolutionary synthesis. Bio-complexity 2017; 2: $1-7$.

11. Merlin F. Evolutionary chance mutation: A defense of the modern synthesis' consensus view. Philosophy and Theory in Biology 2010; 2: e103.

12. Dawkins R. El gen egoista. Barcelona: Salvat Ciencia; 1990.

13. Mayr E. What evolution is New York: Basic Books; 2001: 188.

14. Artigas M, Turbón D. Origen del hombre. Ciencia, filosofía y religión. Pamplona: EUNSA; 2008: 47.

15. Kimura M. Evolutionary rate al the molecular level. Nature 1968; 127: 624-626.

16. Barbadilla A, Casillas S, Ruiz A. La teoría neutralista de la evolución molecular medio siglo después. Investigación y Ciencia 2019 Febrero; 52-59.

17. Eldredge N, Gould SJ. Punctuated Equilibria: The Tempo and Mode of Evolution Reconsidered. Paleobiology 1977; 3: $115-151$

18. Koonin EV. The logic of chance: the nature and origin of biological evolution p.vii. Upper Saddle River: Pearson Education; 2012.

19. Laland K, Uller T, Feldman M, Sterelny K, Müller GB, Moczetz A, et al. Does evolutionary theory need a rethink? Nature 2014; 514: 161-164.

20. Bonduriansky R, Day T. Extended heredity. A new understanding of inheritance and evolution. Princeton, NJ: Princeton University Press; 2018: 151.

21. Youngston NA, Whitelaw E. Transgenerational epigenetic effects. Annual review of genomics and human genetics 2008; 9: 233-257.

22. Erwin DH. Macroevolution of ecosystem engineering, niche construction and diversity. Trends in ecology and evolution 2008; 23: 304-310.

23. West-Eberhard MJ. Developmental plasticity and evolution. New York: Oxford University Press; 2003: 174.

24. Laland K, Uller T, Feldmand MW, Sterelny K, Müller GB, Moczek A, et al. The extended evolutionary synthesis: its structure, assumptions and predictions. Proc. R. Soc B. 2015; 282(1813).

25. Shapiro JA. Evolution Evolution: A View from the 21st Century. Upper Saddle River; 2011.

26. Falkenberg KJ, Laland KN. Extended Heredity: An interview with Russell Bonduriansky and Troy Day. Extended Evolutionary Synthesis: An integrative research program 2018 July 31.

27. Zimmer C. What is a species? Scientific American 2008 June.

28. Mayr E. Principles of Systematic Zoology. Nueva York: McGraw-Hill; 1969.

29. Wiley EO. The evolutionary species concept reconsidered. Systematic biology 1978; 27: 17-21.

30. Wright $S$. The roles of mutation, inbreeding, crossbreeding, and selection in evolution. In Jones DF, editor. Proceedings of the sixth international congress of genetics. Austin, TX: Genetics Society of America; 1932: 356-66.

31. Margulies L. Origin of eukaryotic cells:evidence and research implications. New Haven, CN: Yale University Press; 1970.

32. Maynard Smith J, Szathmáry E. The major transitions in evolution. Oxford: Oxford University Press; 1995.

33. Aznar J. Is there a purpose in the biological evolution of living beings? National Catholic Bioethics Quarterly (in press).

34. Doudna JA, Sternberg SH. Una grieta en la creación. CRISPR, la edición genética y el increíble poder de controlar la evolución. Madrid: Alianza editorial; 2020 p. 18.

35. Weber M. The Protestant Ethic and the Spirit of Capitalism. New York: Routledge; 1992: 181-183. 
36. Roco MC, Bainbridge WS. Converging Technologies for Improving Human Performance. Nanotechnology, biotechnology, information technology and cognitive science. Dordrecht, The Netherlands: Kluwer Academic Publishers (currently Springer); 2003.

37. Monterde R. Pornografía y transhumanismo. Disponible en https://entrelascumbres.blogspot.com/2019/08/pornografia-y-transhumanismo.html. [Online].

38. Juengst ET. What Does Enhancement means? In Parens E. Enhancing Human Traits: Ethical and Social Implication. Washington DC: Georgetown University Press; 1998: 29-47.

39. Dieguez A. Transhumanismo. La búsqueda tecnológica del mejoramiento humano. Barcelona: Herder; 2017.

40. Huxley J. Ensayos de un biólogo. Buenos Aires: Editorial Sudamericana; 1949: 12.

41. Dawkins R. El relojero ciego. Barcelona: Labor; 1988.

42. Colombetti E. Contemporary post-humanism: technological and human singularity. Cuadernos de Bioética 2014; 25: 367-378.

43. Postigo E. Transhumanismo y post-humano: principios teóricos e implicaciones bioéticas. Medicina e Morale. 2009; 2: 267-282.

44. Nietzsche F. Asi habló Zaratustra. Biblioteca digital abierta; 2017: 11.

45. Barrios FD. Transhumanos, superhombres y máquinas humanas: Nietzsche contra la metafísica. Tesis para optar al grado de Doctor, Universidad Complutense de Madrid; 2018.

46. Monod J. El azar y la necesidad. Barcelona: Metatemas Tusquets; 1981: 50.

47. Monterde R. El transhumanismo de Julian Huxley: una nueva religión para la humanidad. Cuadernos de Bioética 2020; 31(101): 71-85.

48. Kurzweil R. La era de las máquinas espirituales. Madrid: Planeta; 1999: 183.

49. Laszlo E. El cambio cuántico. Cómo el nuevo paradigma científico puede cambiar la sociedad. Barcelona: Kairós; 2009.

50. Houllebecq M. Las partículas elementales. Barcelona: Anagrama; 1999.

51. Huxley A. Un mundo feliz. Barcelona: Debolsillo; 2014.

52. Echarte LE. Neurocosmética, transhumanismo y materialismo eliminativo: Hacia nuevas formas de eugenesia. Cuadernos de Bioética 2012; 23: 37-51.

53. Spaemann R. Lo natural y lo racional. Madrid: Rialp; 1989: 46.

54. Spaemann R. Ensayos Filosóficos. Madrid: Cristiandad; 2004: 39.

55. Spaemann R. ¿Bajo qué condiciones se puede hablar todavía de progreso?. In Spaemann R. Ensayos Filosóficos. Madrid: Cristiandad; 2004: 155.

56. Marías J. Antropología Metafísica. Madrid: Alianza Editorial; 1995: 43.

57. Diéguez A. La lucha contra el envejecimiento: un problema científico y filosófico. Encuentros en la Biología 2016; 9: 160-164.

58. Habermas J. El futuro de la naturaleza humana. ¿Hacia una eugenesia liberal? Barcelona: Paidós; 2001.

Recibido: 23 de abril de 2020

Aceptado: 16 de septiembre de 2020 